\title{
Mitochondrial genome of the shorthead catfish (Pelteobagrus eupogon): structure, phylogeny, and intraspecific variation
}

\author{
R.-Q. Wang, D.-Z. Wang, C.-T. Li and X.-R. Yang \\ Department of Biology, Zunyi Normal College, Zunyi, Guizhou, China \\ Corresponding author: R.Q. Wang \\ E-mail: 610194977@qq.com \\ Genet. Mol. Res. 15 (2): gmr.15028634 \\ Received March 23, 2016 \\ Accepted April 11, 2016 \\ Published May 13, 2016 \\ DOI http://dx.doi.org/10.4238/gmr.15028634
}

\begin{abstract}
The complete 16,532-nucleotide sequence of the mitochondrial genome of the shorthead catfish (Pelteobagrus eupogon) was determined using the long and accurate polymerase chain reaction method, and compared with the mitochondrial genome sequences of 49 other catfish species belonging to the order Siluriformes. The locations of protein-coding genes and ribosomal ribonucleic acids (RNAs) were identified by comparison with known sequences of other catfishes, including $P$. fulvidraco and $P$. nitidus. The $P$. eupogon mitochondrial genome was composed of 13 protein-coding genes, two ribosomal RNAs, 22 transfer RNA genes, and a non-coding control region. The gene order was identical to that of other Siluriformes. Phylogenetic analyses based on mitochondrial $12 \mathrm{~S}$ ribosomal RNA, 16S ribosomal RNA, and 13 protein-coding gene sequence data sets were carried out to further clarify the relative phylogenetic position of $P$. eupogon, and identify phylogenetic relationships among 24 families of Siluriformes. Phylogenetic analyses Randomized Axelerated Maximum Likelihood (RAxML) 8.0.X were congruent with a basal split of the order into Clupeiformes, Characiformes, Cypriniformes, and Siluriformes, and
\end{abstract}


supported a closer relationship of $P$. eupogon with Amblycipitidae than Siluridae. We therefore concluded that this species appears to be closely related to the Amblycipitidae. In the phylogenetic tree, the Amblycipitidae appeared as the most basal extant lineage within the Siluriformes, while the Bagridae appeared as the sister group of Cranoglanididae and Pangasiidae. The mitochondrial genome sequence of $P$. eupogon has been deposited in GenBank (accession No. KJ001784).

Key words: Intraspecific variation; Mitochondrial genome; Phylogeny; Shorthead catfish

\section{INTRODUCTION}

Mitochondrial DNA is commonly used in population and phylogenetic studies due to its maternal mode of inheritance and relatively low recombination rate (Curole and Kocher, 1999). The mitochondrial DNA (mtDNA) of most animals is a self-replicating, circular DNA molecule, approximately $16 \mathrm{~kb}$ long, that codes for 13 mitochondrial proteins, 22 mitochondrial tRNAs, and two mitochondrial specific ribosomal RNAs (12S and 16S rRNA). It also contains DNA regions that control its replication and transcription (control region). From an evolutionary viewpoint, mtDNAs are "small genomes" that co-evolve at their own rate within the organism in which they reside (Peng et al., 2006).

Catfishes (Siluriformes) are widely distributed across all continents of the globe. In China, Siluriformes are composed of 11 families (Chen, 1977), the most widely distributed of which is the Bagridae family that includes the shorthead catfish (Pelteobagrus eupogon). Many Bagridae species are economically important in China, and the genetic diversity of wild populations is crucial for artificial culture. However, wild populations of these species have rapidly declined in recent years due to overfishing, pollution, and human other disturbances. Therefore, it is important to assess the genetic diversity of wild populations, to understand the impact that such rapid declines in populations have had. With the recent improvement of molecular techniques, it has become comparatively easier to obtain complete sequences of mitochondrial genomes.

In this study, we analyzed the complete DNA sequence and structure of the mitochondrial genome of shorthead catfish from the Hokiang, a tributary of the Yangtze River. We also assessed phylogenetic relationships within the order Siluriformes in combination using the mitochondrial genomes of other fishes (Table 1). To date, five mitochondrial genomes from four species in the genus Pelteobagrus have been reported to GenBank, including two from P. eupogon (Table 1). Thus, genetic variation can be analyzed across different geographical populations. Our findings provide a strong basis for evaluating the genetic diversity of catfish species in natural populations.

\section{MATERIAL AND METHODS}

\section{Fish samples and DNA extraction}

A shorthead catfish (P. eupogon) specimen was collected from the Hokiang in Sichuan 
Province, China, and identified from morphology as described previously (Wu, 1989). The nuclear and mitochondrial DNA as extracted from muscle tissues using a 3S Spin Genomic DNA Miniprep Kit (Shanghai, China) following the manufacturer's protocol.

Table 1. Mitochondrial genome information for fishes in Siluriformes and other related orders.

\begin{tabular}{|c|c|c|}
\hline Species & GenBank ID & Source \\
\hline \multicolumn{3}{|l|}{ Siluriformes } \\
\hline Amphilius sp NM-2010 & AP012002 & Nakatani et al. (2011) \\
\hline Amblydoras gonzalezi & AP012001 & Nakatani et al. (2011) \\
\hline Auchenoglanis occidentalis & AP012005 & Nakatani et al. (2011) \\
\hline Astroblepus sp NM-2010 & AP012004 & Nakatani et al. (2011) \\
\hline Bunocephalus coracoideus & AP012006 & Nakatani et al. (2011) \\
\hline Chaca bankanensis & AP012008 & Nakatani et al. (2011) \\
\hline Centromochlus perugiae & AP012024 & Nakatani et al. (2011) \\
\hline Cetopsidium sp NM-2010 & AP012007 & Nakatani et al. (2011) \\
\hline Chrysichthys sp NM-2010 & AP012009 & Nakatani et al. (2011) \\
\hline Clarias sp NM-2010 & AP012010 & Nakatani et al. (2011) \\
\hline Corydoras rabauti & AB054128 & Saitoh et al. (2003) \\
\hline Cranoglanis bouderius & AY898626 & Peng et al. (2006) \\
\hline Diplomystes nahuelbutaensis & AP012011 & Nakatani et al. (2011) \\
\hline Glyptothorax fokiensis & JQ917224 & Zhou et al. (2012) \\
\hline Hara jerdoni & AP012012 & Nakatani et al. (2011) \\
\hline Hemibagrus macropterus & JF834542 & Zeng et al. (2012) \\
\hline Helogenes marmoratus & AP012014 & Nakatani et al. (2011) \\
\hline Heteropneustes fossilis & AP012013 & Nakatani et al. (2011) \\
\hline Ictalurus punctatus & AF482987 & Waldbieser et al. (2003) \\
\hline Leiocassis crassilabris & JX867257 & Liang et al. (2013) \\
\hline Leiocassis longirostris & GU596454 & Wang et al. (2011) \\
\hline Liobagrus kingi & Kc193779 & Jia et al. (2013a) \\
\hline Liobagrus marginatoides & Kc473938 & Jia et al. (2013b) \\
\hline Liobagrus nigricauda & KC316116 & Jia et al. (2013c) \\
\hline Liobagrus obesus & DQ321752 & Kartavtsev et al. (2007) \\
\hline Liobagrus reinii & AP012015 & Nakatani et al. (2011) \\
\hline Malapterurus electricus & AP012016 & Nakatani et al. (2011) \\
\hline Pangasianodon gigas & AY762971 & Jondeung et al. (2007) \\
\hline Pangasius larnaudii & AP012018 & Nakatani et al. (2011) \\
\hline Pareutropius debauwi & AP012017 & Nakatani et al. (2011) \\
\hline Pelteobagrus eupogon & JQ734476 & Wang et al. (2013) \\
\hline Pelteobagrus eupogon & KJ001784 & Wang et al. (this study) \\
\hline Pelteobagrus fulvidraco & HM641815 & Liang et al. (2012a) \\
\hline Pelteobagrus nitidus & HM746659 & Liang et al. (2012b) \\
\hline Pelteobagrus vachellii & HM746660 & Liang et al. (2011) \\
\hline Pimelodus pictus & AP012019 & Nakatani et al. (2011) \\
\hline Plotosus japonicas & AP012020 & Nakatani et al. (2011) \\
\hline Pseudobagrus brevicaudatus & JX867256 & Liang et al. (2014a) \\
\hline Pseudobagrus brevicorpus & HM355585 & Kim et al. (2011) \\
\hline Pseudobagrus tokiensis & $\mathrm{AB} 054127$ & Saitoh et al. (2003) \\
\hline Pseudobagrus truncatus & JX867259 & Liang et al. (2014b) \\
\hline Pseudobagrus ussuriensis & KC188782 & Wan et al. (2013) \\
\hline Pterygoplichthys disjunctivus & AP012021 & Nakatani et al. (2011) \\
\hline Sciades seemanni & AP012003 & Nakatani et al. (2011) \\
\hline Silurus asotus & JX087351 & Wang et al. (2015) \\
\hline Silurus glanis & AM398425 & Vittas et al. (2011) \\
\hline Silurus lanzhouensis & JF895472 & Wang et al. (2012) \\
\hline Silurus meridionalis & JX087350 & Wang et al. (2015) \\
\hline Synodontis schoutedeni & AP012023 & Nakatani et al. (2011) \\
\hline Trichomycterus areolatus & AP012026 & Nakatani et al. (2011) \\
\hline Tetranematichthys quadrifilis & AP012025 & Nakatani et al. (2011) \\
\hline \multicolumn{3}{|l|}{ Outgroup } \\
\hline \multicolumn{3}{|l|}{ Cypriniformes } \\
\hline Crossostoma lacustre & M91245 & Tzeng et al. (1992) \\
\hline \multicolumn{3}{|l|}{ Clupeiformes } \\
\hline Sardinops melanostictus & $\mathrm{AB} 032554$ & Inoue et al. (2000) \\
\hline \multicolumn{3}{|l|}{ Characiformes } \\
\hline Phenacogrammus interruptus & AB054129 & Saitoh et al. (2003) \\
\hline
\end{tabular}




\section{PCR amplification and sequencing}

A total of seven long and accurate polymerase chain reaction (LA-PCR) primer pairs were designed by primer premier 5.0 (Table 2), based on the complete mitochondrial genome of P. fulvidraco (GenBank ID HM641815). Two short fragments were amplified to link the long fragments based on their sequences.

Table 2. PCR primers for Pelteobagrus eupogon mtDNA amplification.

\begin{tabular}{l|l|l|l|c}
\hline Forward & Sequence $\left(5^{\prime}-3^{\prime}\right)$ & Reverse & Sequence (5'-3') & Size (bp) \\
\hline Phe-ND2 F & AATCAAAGCATAACACTG & Phe-ND2 R & GCTTATGAATGTGAGGGT & 4100 \\
\hline ND1-Trp F & AAACTTCCTGCCCCTGAC & ND1-Trp R & GAATGCTCGCTGGCTTGA & 2500 \\
\hline ND2-CO2 F & CAGCGAGCATTCATCTAC & ND2-CO2 R & GAACGGCTTCTACAACAA & 2600 \\
\hline Ser-ND3 F & TTACCACCAAACTCACCA & Ser-ND3 R & GAAGAATCGTAGGGAAAA & 2500 \\
\hline CO3-ND5 F & TGCCTGATATTGACACTT & CO3-ND5 R & GCAGACTTTCCAGTAGCG & 3000 \\
\hline ND5-Cytb F & TCGGCTGAGAAGGAGTAGGA & ND5-Cytb R & TAGGGATGCGAGGGCTGT & 2600 \\
\hline Cytb-12S F & CTACAAAGACATTCTAGGGTTC & Cytb-12S R & ATGGCTAAGCATAGTGGG & 2000 \\
\hline
\end{tabular}

Long and accurate PCR (LA-PCR) was carried out in $50 \mu \mathrm{L}$ reactions containing 5 $\mu \mathrm{L}$ 10X LA PCR buffer II, $8 \mu \mathrm{L} 1.5 \mathrm{mM}$ mix dNTPs, $2 \mu \mathrm{L}$ each primer at $10 \mu \mathrm{M}, 0.5 \mathrm{U}$ LA Taq polymerase (Takara, Dalian China), and approximately $50 \mathrm{ng}$ template DNA. The thermal cycle profile was: pre-denaturation at $94^{\circ} \mathrm{C}$ for 4 min; 40 cycles of denaturation at $94^{\circ} \mathrm{C}$ for 60 $\mathrm{s}$; annealing at $50^{\circ} \mathrm{C}$ for $60 \mathrm{~s}$; extension at $72^{\circ} \mathrm{C}$ for $5 \mathrm{~min}$; final extension at $72^{\circ} \mathrm{C}$ for $10 \mathrm{~min}$. The PCR mixture for short fragments was the same as in LA-PCR, with the exception that the first extension time was changed to $1 \mathrm{~min}$ in the PCR program. PCR products were sent to Biosune Biotech Company (Beijing) for sequencing with primer walking.

\section{Data analysis}

DNA sequences were analyzed using the Sequencing Analysis software v 3.4.1 (Applied Biosystems, USA) and SeqMan v 5.05 (DNASTAR Inc., USA). The locations of protein-coding genes and rRNAs were identified by comparison with known sequences of other catfishes, including P. fulvidraco (GenBank ID: HM641815), (Liang et al., 2012a) and P. nitidus (GenBank ID: HM746659), (Liang et al., 2012b). Transfer RNA genes were identified by tRNA scan-SE 1.21 (Lowe and Eddy, 1997). Alignment of DNA sequences was performed using ClustalX version 1.81 (Thompson et al., 1997). Phylogenetic relationships were generated from the nucleotide sequences of the mitochondrial genes (including $12 \mathrm{~S}$ and 16S rRNA genes), and the deduced amino acid sequences of each of the 13 complete mitochondrial protein-coding genes, using RAxML 8.0.X Inference (Stamatakis, 2006). The locations of the protein-coding genes and rRNAs were identified based on known sequences of other catfish species, including P. fulvidraco (GenBank ID HM641815) and P. vachelli (GenBank ID HM746660) (Liang et al., 2011). The DNA sequences of the 13 mitochondrial protein-coding genes used for analysis of $P$. eupogon are listed in Table 3.

\section{RESULTS AND DISCUSSION}

\section{Structure of the mitochondrial genome}

The complete mitochondrial genome of P. eupogon, with a total length of 16,532 bp, 
was sequenced and deposited in GenBank (GenBank ID KJ001784). The gene order and genecoding strands in $P$. eupogon:two rRNAs, 22 tRNAs, 13 protein-coding genes, and a control region (Table 3 and Figure 1), were identical to those of the Atlantic cod, Javeline goby, and Japanese flying fish (Johansen and Bakke, 1996; Nagase et al., 2005; Kim et al., 2011). The overall base composition of H-strand in P. eupogon was as follows: A, 30.3\%; C, 28.7\%; G, $16.0 \%$; and $\mathrm{T}, 25.0 \%$.

\begin{tabular}{|c|c|c|c|c|c|c|}
\hline Gene & Abbreviation & Strand & Position & Size & Start codon & Stop codon \\
\hline tRNA $^{\text {Phe }}$ & $\mathrm{F}$ & $\mathrm{H}$ & $1-72$ & 72 & & \\
\hline $12 \mathrm{~S}$ ribosomal RNA & $12 \mathrm{~S}$ & $\mathrm{H}$ & $73-1026$ & 953 & & \\
\hline tRNA & $\mathrm{V}$ & $\mathrm{H}$ & $1027-1098$ & 72 & & \\
\hline $16 \mathrm{~S}$ ribosomal RNA & $16 \mathrm{~S}$ & $\mathrm{H}$ & $1099-2776$ & 1678 & & \\
\hline tRNA & $\mathrm{L}$ & $\mathrm{H}$ & $2777-2851$ & 75 & & \\
\hline NADH dehydrogenase subunit 1 & ND1 & $\mathrm{H}$ & $2852-3826$ & 975 & ATG & TAA \\
\hline tRNA $^{\text {Ile }}$ & I & $\mathrm{H}$ & $3831-3902$ & 72 & & \\
\hline $\mathrm{tRNA}^{\mathrm{GIn}}$ & $\mathrm{Q}$ & $\mathrm{L}$ & $3903-3973$ & 71 & & \\
\hline tRNA $^{\text {Met }}$ & $\mathrm{M}$ & $\mathrm{H}$ & $3973-4041$ & 69 & & \\
\hline NADH dehydrogenase subunit 2 & ND2 & $\mathrm{H}$ & $4042-5088$ & 1047 & ATG & TAG \\
\hline tRNA $^{\text {Trp }}$ & $\mathrm{W}$ & $\mathrm{H}$ & $5087-5157$ & 71 & & \\
\hline tRNA $^{\text {Ala }}$ & $\mathrm{A}$ & $\mathrm{L}$ & $5160-5228$ & 69 & & \\
\hline tRNA $^{\text {Asn }}$ & $\mathrm{N}$ & $\mathrm{L}$ & $5230-5302$ & 73 & & \\
\hline tRNA $^{\text {Cys }}$ & $\mathrm{C}$ & $\mathrm{L}$ & $5334-5400$ & 66 & & \\
\hline tRNA $^{\text {Tyr }}$ & $\mathrm{Y}$ & $\mathrm{L}$ & $5401-5471$ & 71 & & \\
\hline Cytochrome c oxidase subunit 1 & $\mathrm{COI}$ & $\mathrm{H}$ & $5473-7023$ & 1551 & GTG & TAA \\
\hline tRNA ${ }^{\text {Ser }}$ & $\mathrm{S}$ & $\mathrm{L}$ & 7024-7094 & 71 & & \\
\hline tRNA $^{\text {Asp }}$ & $\mathrm{D}$ & $\mathrm{H}$ & 7099-7171 & 73 & & \\
\hline Cytochrome c oxidase subunit 2 & COII & $\mathrm{H}$ & $7186-7876$ & 691 & ATG & T- \\
\hline tRNA ${ }^{\text {Lys }}$ & $\mathrm{K}$ & $\mathrm{H}$ & $7877-7950$ & 74 & & \\
\hline ATP synthase F0 subunit 8 & ATP8 & $\mathrm{H}$ & $7952-8119$ & 168 & ATG & TAA \\
\hline ATP synthase F0 subunit 6 & ATP6 & $\mathrm{H}$ & $8110-8793$ & 684 & ATG & TAA \\
\hline Cytochrome c oxidase subunit 3 & COIII & $\mathrm{H}$ & $8793-9576$ & 784 & ATG & T- \\
\hline tRNA $^{\text {Gly }}$ & $\mathrm{G}$ & $\mathrm{H}$ & $9577-9650$ & 74 & & \\
\hline NADH dehydrogenase subunit 3 & ND3 & $\mathrm{H}$ & $9651-10001$ & 351 & ATG & TAG \\
\hline tRNA $^{\text {Arg }}$ & $\mathrm{R}$ & $\mathrm{H}$ & $10000-10070$ & 71 & & \\
\hline NADH dehydrogenase subunit 4L & ND4L & $\mathrm{H}$ & 10071-10367 & 297 & ATG & TAA \\
\hline NADH dehydrogenase subunit 4 & ND4 & $\mathrm{H}$ & 10361-11741 & 1381 & ATG & T- \\
\hline tRNA $^{\text {His }}$ & $\mathrm{H}$ & $\mathrm{H}$ & $11742-11811$ & 70 & & \\
\hline tRNA ${ }^{\text {Ser }}$ & $\mathrm{S}$ & $\mathrm{H}$ & $11812-11882$ & 71 & & \\
\hline tRNA ${ }^{\text {Leu }}$ & $\mathrm{L}$ & $\mathrm{H}$ & $11883-11955$ & 73 & & \\
\hline NADH & ND5 & $\mathrm{H}$ & $11956-13782$ & 1827 & ATG & TAA \\
\hline NADH & ND6 & $\mathrm{L}$ & $13779-14294$ & 516 & ATG & TAA \\
\hline tRNA $^{\text {Glu }}$ & E & $\mathrm{L}$ & $14295-14363$ & 69 & & \\
\hline Cytochrome & Cyt B & $\mathrm{H}$ & $14366-15503$ & 1138 & ATG & T- \\
\hline tRNA $^{\text {Thr }}$ & $\mathrm{T}$ & $\mathrm{H}$ & $15504-15576$ & 73 & & \\
\hline tRNA $^{\text {Pro }}$ & $\mathrm{P}$ & $\mathrm{L}$ & $15575-15644$ & 70 & & \\
\hline Displacement loop (control region) & D-loop & $\mathrm{H}$ & $15645-16532$ & 888 & & \\
\hline
\end{tabular}

The protein-coding genes in the P. eupogon mitochondrial genome utilize ATG as a start codon, except for COI that initiated with GTG (Table 3). These findings are similar to the dogfish, Chinese longsnout catfish, and Yellow River catfish (Delarbre et al., 1998; Wang et al., 2011; Wang et al., 2012), Nine open reading frames ended with TAA or TAG, and the remaining genes had an incomplete stop codon T (Table 3). In P. eupogon, overlaps were found in ATP8-ATP6 (10 bp) and ND4-ND4L (7 bp), which occurred on the same strand, and in ND5-ND6 (5 bp) located on different strands.

The mitochondrial genome of $P$. eupogon contained 22 tRNA genes, ranging from 66 to $75 \mathrm{bp}$ in size. All tRNA genes, except for tRNA ${ }^{\text {Ser }}$ (AGY), were predicted to display the typical cloverleaf secondary structure with normal base pairing. Among these tRNA genes, nine 
were encoded on L-strand, and the remaining on $\mathrm{H}$-strand. The 12S and 16S rRNA genes in $P$. eupogon had 953 and $1678 \mathrm{bp}$, respectively. 12S and 16S rRNA genes were located between the tRNA ${ }^{\text {Phe }}$ and tRNA ${ }^{\text {Leu }}$ genes and separated by the tRNA ${ }^{\mathrm{Val}}$ gene, as in $S$. meridionalis and $S$. asotus (Wang et al., 2015) (Figure 1).

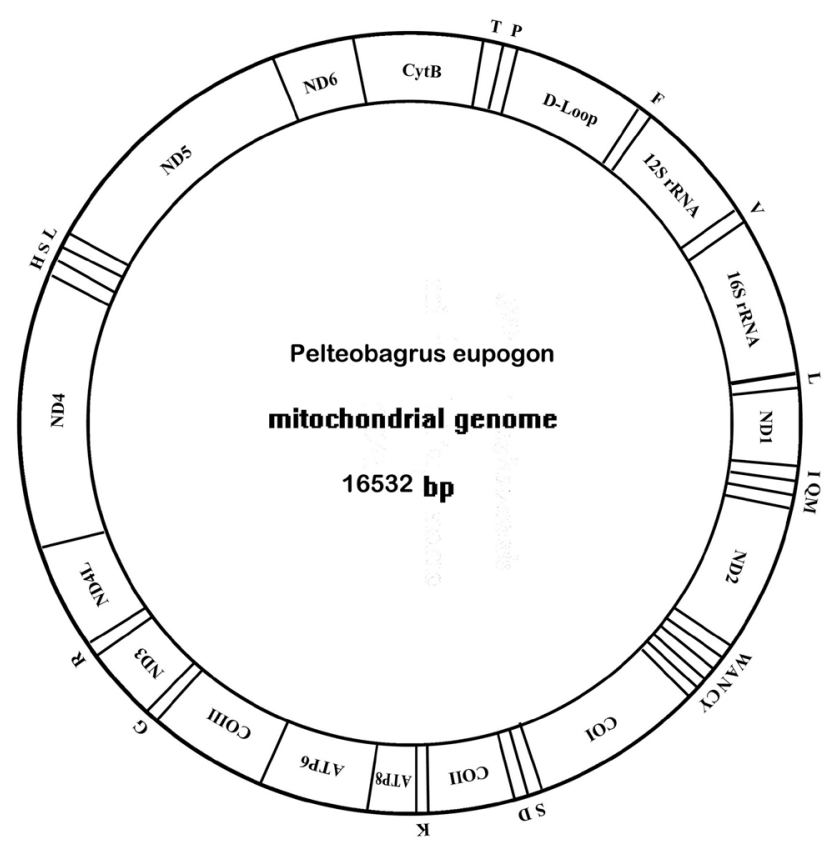

Figure 1. Gene organization of the Pelteobagrus eupogon mitochondrial genome. Gene names and abbreviations are listed in Table 3.

The major non-coding segment of the mitochondrial genome is the control region, which regulates replication and transcription (Inoue et al., 2000; Jondeung et al., 2007). The control region in P. eupogon was 888 bp long. Similar to other fish species (Kim et al., 2005; $\mathrm{Xu}$ et al., 2011), there are three candidates for promoters containing the TATA box conserved sequence block 5'-GTATATATACA-3' (CSB) domains that were found in the control region of P. eupogon: CSB-1 at the 5' end, and CSB-2 and CSB-3 at the 3 ' end (see annotation in GenBank ID KJ001784).

\section{Phylogenetic analysis}

Phylogenetic relationships of $P$. eupogon within the order Siluriformes are shown in Figure 2. Twelve species of catfish in the family Bagridae formed a distinct clade with high bootstrap values (100). This is consistent with the previously determined morphological classification of Bagridae, and its significant differentiation from other families within Siluriformes (Chen, 1977). As expected, the monophyly of Siluriformes, and the inclusion of P. eupogon within this order, were highly supported (bootstrap value of 100). 

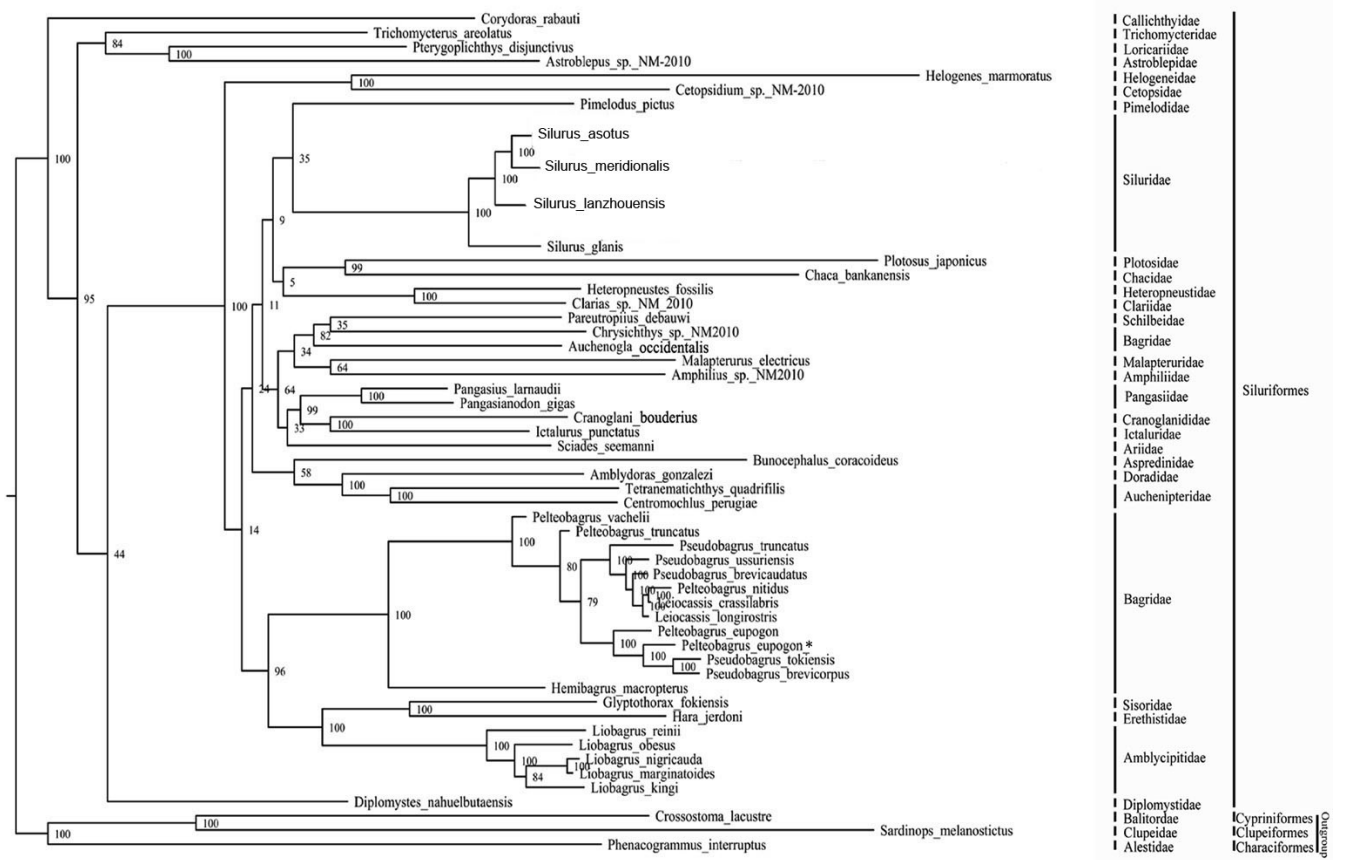

Figure 2. Phylogenetic relationships among Siluriformes as determined by RAxML. Majority rule consensus of maximum likelihood bootstrap measure trees from RAxML inference analysis based on rRNA and protein code data set under the GTR $+\mathrm{I}+\mathrm{G}$ (General Time Reversible; I: invariable sites; G: gamma distribution) model is shown. Branch lengths are mean estimates. Asterisks indicate specimens used in the present study. Numbers in the nodes are from highest to lowest bootstrap value. The scale in the left lower corner indicates relative branch lengths.

The family of Bagridae and a sister group comprising Amblycipitidae, Sisoridae, and Erethistidae were strongly supported (bootstrap value of 96). These findings are consistent with the previously determined morphological classification that Bagridae is significantly differentiated from other families within Siluriformes. Bagridae was recovered with maximal support (bootstrap value of 100) as a sister group of Amblycipitidae. The Sisoridae and Erethistidae families were recovered as other sister groups. The Bagridae and Amblycipitidae families were closely related, however, Chrysichthys sp NM 2010 (Nakatani et al., 2011) and Auchenoglanis occidentalis are excluded from Bagridae.

In other branches, the Schilbeidae, Malapteruridae, Amphiliidae, Cranoglanididae, Pangasiidae, Ariidae, and Ictaluridae families formed a distinct group (bootstrap value of 100). Four catfish species in the family Siluridae formed a distinct clade with high bootstrap support (100), in agreement with the previously determined morphological classification, indicating that the family Siluridae is significantly differentiated from other families within Siluriformes. Siluridae was recovered with maximal support as a sister group of Pimelodus pictus (Pimelodidae), which is consistent with the previous report (Nakatani et al., 2011). The families of Plotosidae, Chacidae, Heteropneustidae, and Clariidae were also recovered as sister groups, however, these relationships were not as well supported (bootstrap value of 9).

Even though phylogenetic interrelationships of highly diversified families of the order Siluriformes are well studied at the molecular level, the main phylogenetic interrelationships 
of families, such as Loricariidae, Trichomycteridae, Astroblepidae, and Callichthyidae, remain largely unresolved. Corydoras rabauti (Callichthyidae), which is assigned to the suborder Loricarioidei, was placed as a sister group to all other analyzed Siluriformes. The family Callichthyidae is an independent clade in the Siluriformes. The phylogenetic relationship of the Siluriformes families obtained in this study were similar to another study based on the entire mitochondrial genome, excluding the control region (Delarbre et al., 1998). At a higher taxonomic level, the monophyly of Otophysi (Cypriniformes, Gymnotiformes, Characiformes, and Siluriformes) was highly supported (bootstrap value of 100) by all methods of phylogenetic inference. We inferred therefore that Siluriformes originate from Characiformes. The monophyly of the different orders within Ostariophysi is well supported on morphological grounds.

\section{Nucleotide variation}

When the mitochondrial genome of $P$. eupogon obtained in the present study was compared with two others submitted to GenBank (Table 4), among the 16589 bp aligned sequences, $9.9 \%$ of the sites were variable. The rRNA genes showed $11.3 \%$ variable sites, and tRNAs were fairly conserved with $3.2 \%$ variable sites. Meanwhile, the control region was more variable at $15.4 \%$. The percentages of variable sites in all 13 protein-coding genes ranged from $2.3 \%$ (COXII) to $19.1 \%$ (ND1), with an average of $10.1 \%$ (Table 4). The specimen of $P$. eupogon in this study was sampled from the Hokiang, the upstream branch of the Yangtze River in Sichuan Province (China), whereas the precise location of the specimen used for comparison was not available from GenBank (GenBank ID JQ733476). However, the intraspecific variation between the two specimens is considerable, and may even suggest that the two specimens are different species.

Table 4. Intraspecific variation of mitochondrial genomes of two Pelteobagrus eupogon individuals (GenBank ID KJ001784 and JQ734476).

\begin{tabular}{l|c|c|c}
\hline & Length of aligned sequence & Number of variable sites & Percentage of variable sites (\%) \\
\hline All sites & 16,589 & 1,640 & 9.9 \\
\hline tRNAs & 1,570 & 51 & 3.2 \\
\hline rRNAs & 2,647 & 298 & 11.3 \\
\hline Control region & 928 & 143 & 15.4 \\
\hline Protein-coding genes & 11,384 & 1,149 & 10.1 \\
\hline ND1 & 975 & 186 & 19.1 \\
\hline ND2 & 1,047 & 126 & 12.0 \\
\hline COX1 & 1,551 & 51 & 3.3 \\
\hline COX2 & 691 & 15 & 2.3 \\
\hline ATP8 & 168 & 5 & 2.9 \\
\hline ATP6 & 684 & 19 & 2.8 \\
\hline COX3I & 784 & 75 & 9.6 \\
\hline ND3 & 351 & 17 & 4.8 \\
\hline ND4L & 297 & 38 & 9.4 \\
\hline ND4 & 1,381 & 199 & 14.4 \\
\hline ND5 & 1,827 & 223 & 12.2 \\
\hline ND6 & 516 & 64 & 12.4 \\
\hline
\end{tabular}

\section{ACKNOWLEDGMENTS}

We thank Ms. Zeng Yanling for collecting field sample. Research supported by the key project of Science \& Technology Department of Guizhou Province [Qiankehe \#NZ 
(2013)3027], the important scientific project in the "125" Program of Guizhou Province [Qianjiaohe \#(2013)025], and the Joint Research Program of Guizhou [\#LKZS (2012)20 and \#LKZS (2012)17].

\section{REFERENCES}

Chen XL (1977). A Review of the Chinese Siluridae. Hydrobiol. Collected Papers 197-216.

Curole JP and Kocher TD (1999). Mitogenomics: digging deeper with complete mitochondrial genomes. Trends Ecol. Evol. 14: 394-398. http://dx.doi.org/10.1016/S0169-5347(99)01660-2

Delarbre C, Spruyt N, Delmarre C, Gallut C, et al. (1998). The complete nucleotide sequence of the mitochondrial DNA of the dogfish, Scyliorhinus canicula. Genetics 150: 331-344.

Inoue JG, Masaki M, Katsumi T and Mutsumi N (2000). Complete mitochondrial DNA sequence of the Japanese sardine, Sardinops melanostictus. Fish. Sci. 66: 924-932. http://dx.doi.org/10.1046/j.1444-2906.2000.00148.x

Jia XY, Li YW, Wang DQ, Tian HW, et al. (2013a).The complete mitochondrial genome of Liobagrus kingi (Teleostei, Siluriformes: Amblycipitidae). Mitochondr. DNA 24: 323-325.

Jia XY, Li YW, Wang DQ, Tian HW, et al. (2013b).The mitogenome of Liobagrus marginatoides (Teleostei, Siluriformes:Amblycipitidae). Mitochondr. DNA 24: 645-647.

Jia XY, Li YW, Wang DQ, Li SH, et al. (2013c).The mitogenome of Liobagrus nigricauda (Teleostei, Siluriformes:Amblycipitidae). Mitochondr. DNA 24: 373-375.

Johansen S and Bakke I (1996). The complete mitochondrial DNA sequence of Atlantic cod (Gadus morhua): relevance to taxonomic studies among codfishes. Mol. Mar. Biol. Biotechnol. 5: 203-214.

Jondeung A, Sangthong P and Zardoya R (2007). The complete mitochondrial DNA sequence of the Mekong giant catfish (Pangasianodon gigas), and the phylogenetic relationships among Siluriformes. Gene 387: 49-57. http://dx.doi. org/10.1016/j.gene.2006.08.001

Kartavtsev YP, Jung SO, Lee YM, Byeon HK, et al. (2007).Complete mitochondrial genome of the bullhead torrent catfish, Liobagrus obesus (Siluriformes, Amblycipitidae): Genome description and phylogenetic considerations inferred from the Cyt b and 16S rRNA genes. Gene 396: 13-27.

Kim IC, Jung SO, Lee YM, Lee CJ, et al. (2005). The complete mitochondrial genome of the rayfish Raja porosa (Chondrichthyes, Rajidae). DNA Seq. 16: 187-194. http://dx.doi.org/10.1080/10425170500087975

Kim SK, Choi EH, Hong KB, Jang KH, et al. (2011). Complete mitochondrial genome of the Korean stumpy bullhead Pseudobagrus brevicorpus (Siluriformes, Bagridae). Mitochondrial DNA 22: 44-46. http://dx.doi.org/10.3109/1940 $\underline{1736.2011 .597388}$

Liang HW, Li L, Li Z, Zou GW, et al. (2011). Phylogenetic analysis of Silurus meridionalis based on the complete mitochondrial DNA sequence. J. Northwest $A \&$ \& Univ. 39: 80-88.

Liang HW, Cao L, Li Z, Zou GW, et al. (2012a). Mitochondrial genome sequence of the shining catfish (Pelteobagrus nitidus). Mitochondrial DNA 23: 280-282. http://dx.doi.org/10.3109/19401736.2012.683185

Liang HW, Hu GF, Li Z, Zou GW, et al. (2012b). Mitochondrial DNA sequence of yellow catfish (Pelteobagrus fulvidraco). Mitochondrial DNA 23: 170-172. http://dx.doi.org/10.3109/19401736.2012.668899

Liang HW, Li Z and Zou W (2013). Complete mitochondrial DNA genome of Leiocassis crassilabris (Siluriformes: Bagridae). Mitochondr. DNA 24: 222-224.

Liang HW, Meng Y, Li Z, Zhang Y, et al. (2014a). Complete mitochondrial DNA genome of Pseudobagrus brevicaudatus (Siluriformes: Bagridae). Mitochondr. DNA 25: 179-180.

Liang HW, Meng Y, Li Z, Zhang Y, et al. (2014b). Complete mitochondrial DNA genome of Pseudobagrus truncatus (Siluriformes: Bagridae). Mitochondr. DNA 25: 179-180.

Lowe TM and Eddy SR (1997). tRNAscan-SE: a program for improved detection of transfer RNA genes in genomic sequence. Nucleic Acids Res. 25: 955-964. http://dx.doi.org/10.1093/nar/25.5.0955

Nagase M, Aimi T, Suginaka K, Kitamoto Y, et al. (2005). Complete mitochondrial DNA sequence of the Japanese flying fish Cypselurus hiraii. Fish. Sci. 71: 914-923. http://dx.doi.org/10.1111/j.1444-2906.2005.01045.x

Nakatani M, Miya M, Mabuchi K, Saitoh K, et al. (2011). Evolutionary history of Otophysi (Teleostei), a major clade of the modern freshwater fishes: Pangaean origin and Mesozoic radiation. BMC Evol. Biol. 11: 177. http://dx.doi. org/10.1186/1471-2148-11-177

Peng Z, Wang J and He S (2006). The complete mitochondrial genome of the helmet catfish Cranoglanis bouderius (Siluriformes: Cranoglanididae) and the phylogeny of otophysan fishes. Gene 376: 290-297. http://dx.doi. org/10.1016/j.gene.2006.04.014 
Saitoh K, Miya M, Inoue JG, Ishquro NB, et al. (2003). Mitochondrial genomics of ostariophysan fishes: perspectives on phylogeny and biogeography. J. Mol. Evol. 56: 464-472.

Stamatakis A (2006). RAxML-VI-HPC: maximum likelihood-based phylogenetic analyses with thousands of taxa and mixed models. Bioinformatics 22: 2688-2690. http://dx.doi.org/10.1093/bioinformatics/btl446

Thompson JD, Gibson TJ, Plewniak F, Jeanmougin F, et al. (1997). The CLUSTAL_X windows interface: flexible strategies for multiple sequence alignment aided by quality analysis tools. Nucleic Acids Res. 25: 4876-4882. http:// dx.doi.org/10.1093/nar/25.24.4876

Tzeng CS, Hui CF, Shen SC. (1992). The complete nucleotide sequence of the Crossostoma lacustre mitochondrial genome: conservation and variations among vertebrates. Nucleic Acids Res. 20: 4853-4858.

Vittas S, Drosopoulou E, Kappas I, Pantzartzi CN, et al. (2011). The mitochondrial genome of the European catfish Silurus glanis (Siluriformes, Siluridae). J. Biol. Res. 15: 25-35.

Waldbieser GC, Bilodeau AL and Nonneman DJ (2003). Complete sequence and characterization of the channel catfish mitochondrial genome. DNA Seq. 14: 265-277.

Wan Q, Tao G, Cheng Q, ChenY, et al. (2013). The complete mitochondrial genome sequence of Pseudobagrus ussuriensis (Siluriformes: Bagridae). Mitochondr. DNA 24: 333-335.

Wang J, Shen T, Ju J and Yang G (2011). The complete mitochondrial genome of the Chinese longsnout catfish Leiocassis longirostris (Siluriformes: Bagridae) and a time-calibrated phylogeny of ostariophysan fishes. Mol. Biol. Rep. 38: 2507-2516. http://dx.doi.org/10.1007/s11033-010-0388-4

Wang QR, Xu C, Xu CR and Wang RJ (2012). Mitochondrial genome structure of yellow river catfish (Silurus lanzhouensis) and phylogenetic analysis. Acta Sci. Nat. Univ. Pekinensis. 28: 376-380.

Wang XY, Cao L, Liang HW, Li Z, et al. (2013). Mitochondrial genome of the Shorthead catfish (Pelteobagrus eupogon). Mitochondr. DNA 24: 1-2.

Wang QR, Xu C, Xu CR and Wang RJ (2015). Complete mitochondrial genome of the Southern catfish (Silurus meridionalis Chen) and Chinese catfish ( $S$. asotus Linnaeus): Structure, phylogeny, and intraspecific variation. Genet. Mol. Res. 14: 18198-18209. http://dx.doi.org/10.4238/2015.December.23.7

Wu L (1989). The Fishes of Guizhou Province. People's Publishing House of Guizhou, Guiyang.

Xu TJ, Cheng YZ, Sun YN, Shi G, et al. (2011). The complete mitochondrial genome of bighead croaker, Collichthys niveatus (Perciformes, Sciaenidae): structure of control region and phylogenetic considerations. Mol. Biol. Rep. 38: 4673-4685. http://dx.doi.org/10.1007/s11033-010-0602-4

Zeng Q, Ye H, Peng Z and Wang Z (2012). Mitochondrial genome of Hemibagrus macropterus (Teleostei, Siluriformes). Mitochondr. DNA 23: 355-357.

Zhou C, Wang D, Yu M and He S (2012). The complete mitochondrial genome of Glyptothorax fukiensis fukiensis (Teleostei, Siluriformes: Sisoridae). Mitochondr. DNA 23: 414-416. 